\title{
A.G.M. of the Hegel Society of Great Britain 1987
}

The Annual General Meeting was held in the course of last year's conference with Professor Leon Pompa in the chair. Dr. Howard Williams was elected Secretary/Treasurer to replace Dr. Stephen Houlgate who has taken up a post at De Paul University, Chicago.

A draft constitution was presented to the meeting and discussed. Proposals for a joint Anglo-Italian conference to be held from 6 to 9 April 1989 were discussed and it was agreed that Dr. Pelczynski, Professor Pompa and Dr. Bellamy should form a selection committee to receive papers from possible participants.

It was agreed that the price of the Bulletin should be increased to $f 9$ for institutions.

\section{North American Kant Society}

Members of the Hegel Society of Great Britain will be interested to learn of the North American Kant Society which was formed on 10 September 1985. The Society is open to anyone with a scholarly interest in the works of Immanuel Kant. The Society sponsors scholarly programmes at the Central Division American Philosophical Association (where it also holds its annual business meeting) and elsewhere. It publishes a regular newsletter containing matters of interest to Society members and Kant scholars generally: conferences, publications and the like. Submission of items for the newsletter is invited. Further information and application forms can be obtained from Professor Hoke Robinson, Department of Philosophy, Memphis State University, Memphis TN 38152, USA. Dues are $\$ 20$ a year regular, $\$ 10$ for students and underemployed.

\section{Arrangements for Purchasing The Owl of Minerva}

In an exchange agreement between the Hegel Society of America and the Hegel Society of Great Britain which is intended to help our readership avoid the costs involved in obtaining international money orders in foreign currency, any member of the Hegel Society of Great Britain wanting a one-year membership in the Hegel Society of America can join by sending $£ 7.50$ directly to the Secretary of the Hegel Society of Great Britain whose address can be found at the beginning of this Bulietin. Cheques should be made out to the Hegel Society of Great Britain. Membership of the Hegel Society of America includes a subscription to The OM/ of Minerva. 